\title{
Analysis of Scholarship Program for Strengthening the Reforming Institution BPKP
}

\author{
Mohammad Sofyan ${ }^{1}$, Soleh ${ }^{2}$, Tjiptadi, Deni Sutisna \\ ${ }^{1}$ Faculty of Administrative Sciences, STIAMI Institute of Social Sciences and Management \\ ${ }^{2}$ Faculty of Social and Political Sciences, Wiralodra University \\ soleh_hs@yahoo.com
}

Submitted: February $22^{\text {th }}, 2020$

Revised: March $25^{\text {th }}, 2020$

Published: March $30^{\text {th }} 2020$

\begin{abstract}
The purpose of the Scholarship Program for Strengthening the reforming institution (SPIRIT) is to build the capacity of participating institutions by (i) strengthening human resources in critical functional areas; and (ii) improving their ability to start and manage reforms. The study showed that the Transfer of Knowledge by the SPIRIT Alumni in the Unit of work could not be measured objectively. Transfer Knowledge conducted by SPIRIT alumni is generally informally to complete the work is judged to have a relatively high difficulty level of SPIRIT Alumni are usually able to apply their knowledge and skills with teammates/colleagues in their units.
\end{abstract}

Keywords: SPIRIT, Scholarship, Transfer of Knowledge, human resources, performance.

\section{INTRODUCTION}

The country setting Program as organized on four pillars: 1) Increasing transparency and EFI financial management of government finance, 2) improving the EFI of community service delivery, 3) strengthening checks and rechecking, and 4) supporting Open and transparent competition. This cross-sector focus will use to improve coordination and provide strategic focus. In public financial management, The focus is on practical and transparent taxation and budget systems (SPIRIT, SPAN, SMART). Involvement in improving the delivery of community services focuses on improving the system (including procurement) and the feedback mechanism of the population (DAK, PNPM, BOS). The field of examination and re-examining, the GAC team partners with Indonesian institutions that lead the eradication of corruption (such as the $\mathrm{KPK}$ ) and engage with the CSOS to strengthen the efforts. To support open and transparent competition, the World Bank focuses on resources, including through EITI and REDD +, support for regulatory framework and reform of the financial sector.

The government recognizes the importance of institutional reform and capacity building. The National Medium Term Development Plan (RPJMN) year 2010-2014 identifies bureaucracy and government reform as one of eleven national priorities. The world Bank's State Partnership Strategy (2009-12) also centred on the institutional development plan. The world Bank has supported these measures through various means, such as the Development Loan Policy (KPP) and the DPL Infrastructure network (Government financial management and Project revenue Administration (MKPAPP), and the Indonesian Administrative Tax Reform (PINTAR) project, economic and employment sectors, technical assistance.

Impressive progress has indeed been achieving in recent years in the capacity building and accountability of several public sector institutions. At the central government, these initiatives to improve the investment through regulatory reform; improving global financial 
management systems, which involve reforms in budget preparation, implementation, auditing and procurement; remuneration of civil servants and change management in critical ministries; and improvements to improve critical institutional infrastructure. This reform incomplete, and the focus in the medium term must remain on developing several core systemic processes and institutions to formulate and implement policies, including public financial management systems, civil service capacity and accountability, decentralization frameworks, corruption control, and the justice and legal systems(Ainal, 2015; Fitri, 2015).

The increased skills of government staff involved in formulating and implementing policies are essential elements for regulatory and process improvement and fundamental components of institutional capacity development. When effectiveness a conducive environment for institutional reform, individual training can activate "good circles" for growth, where institutional reform and capacity development progress training, in time Generate incentives required by staff to implement newly acquired skills for job interests in institutions.

The scholarship program to support Bureaucratic Reform in the central government and aims to: (1) improve human resources through developing technical, managerial, and leadership skills in key functional areas; and (2) improve the operation of the internal environment through the ability to carry out bureaucratic reforms within the institution and their impact on the culture and processes of the organization and improvement of the staff's thinking at the institution.

The world Bank's approach to strengthening the public sector is to continue support for development outcomes that will enhance the public sector by improving government financial management. The world Bank supports the Ministry of Finance's efforts to strengthen tax management and strengthen its acceptance sources by including non-tax receipts from mineral resources. Proposed by the DPL will strengthen and expand ownership and commitment to the points of achievement of reforms. Project loans provide technical support and funding through the Government Financial Management and Revenue Administration Project / GFMRAP, Project for Indonesian Tax Administration Reform / PINTAR, Scholarships Program for Strengthening Reforming Institutions Projects (SPIRIT), and the Strengthening Indonesia Statistic Project / STATCAP-CERDAS. Public Finance Management - the Multi-Donor Trust Fund also supports critical activities, gathering together key development partners, including the European Commission, the Netherlands and Switzerland.

The community partnerships that were formed and strengthened throughout the Engaged Department Initiative have led to continuing opioid-related engagement activities with an ever-increasing number of surrounding communities.

The Strengthening Communities Initiative and suggest the role of internal social movements in transforming institutions of higher education and communities. Our model calls for program-initiated service-learning, reciprocal partnerships, and institution-level changes to support engaged teaching and scholarship. Such a transformation requires visionary leadership at the institutional level, external demands for new thinking and acting, and a critical mass of interested faculty and students. Besides, the model suggests that an organizing structure, such as the Strengthening Communities Initiative program, is essential to institutionalize the social movement further and ultimately influence the cultural and philosophical core of institutions of higher education. 
Analysis of Scholarship Program for Strengthening the Reforming Institution BPKP Sofyan, Soleh, Tjiptadi, Sutisna

\section{METHOD}

The study method uses In-depth interview, which aims to Explore more information about the benefits of the SPIRIT program for Alumni and Institutions (Unit work), both for degree programs and Non-degree training programs. The leading information excavated for the degree program includes the implementation of the re-entry program, productivity Alumni, Attitude Alumni, as well as Alumni participation in special events such as ad-hoc assignments, attending national and international seminates both as a resource or participant. Meanwhile, the information that dug related to the Non-degree training Program is the preparation and implementation of the Action Plan, increased skills, efficiency and effectiveness of Alumni work, and the role of Non-graduate training Alumni in special events.

The method of data collection is a process of obtaining and measuring a variety of information about variables examined systematically. The purpose of all data collection is to get real and correct evidence, which can then use for data analysis (Asra et al., 2015).

Literature study; The study of the library is a method of data collection by searching for information through books, magazines, newspapers, and other literature which aims to form a foundation of Theory (Arikunto, 2006). A literature study has conducted to obtain information relating to the investigated issues, which could also use as a solid theoretical basis. The study of the libraries undertaken by researchers in this study is to study documents related to the SPIRIT Program activities.

Interview According to Asra et al. (2015), the method of interviewing is a common way to gather information from people. According to J. Supranto (2012), The interview is a question and answer between the officer and the respondent. Interviews with the primary data source can be done face-to-face with the respondent individually. In this study, researchers interviewed directly with face to boss and colleagues from SPIRIT Alumni to obtain supporting data. The interview has done by In-depth Interview method.

\section{RESULT AND DISCUSSION}

Our analysis of the conceptual literature on engaged scholarship, and more specifically, on its underlying values and principles, and its implications at the individual and institutional levels, sheds new light on this movement. Engaged scholarship is a unique academic paradigm that affects not only the researcher's role but also those of the student and the university in society. Recent years have seen significant changes in the academic environment. It is now widely recognized that, for faculty, working in isolation has become outdated and collaborating with other settings has become essential. As such, new streams are emerging that offer an alternative to traditional scientific approaches.

In the alumni and Participating Agency Staff Survey consultant SPIRIT, in-depth Interview has conducted mainly to explore the benefits obtained by the Alumni and institutions/institutions of the SPIRIT program. This In-depth interview has done by questioning the interviewer with a direct boss and an ALUMNI colleague using structured interview Guidelines.

SPIRIT Alumni capacity building can show in aspects of thinking, conceptual ability, foreign language, the confidence of alumni in completing specific tasks, analytical skills, time effectiveness in completing assignments, promotion of positions.

The increasing capacity of SPIRIT Alumni, this is seen in the aspect: How to think, have excellent analytical skills, increased ability to develop concepts, good foreign language mastery, 
increased confidence of SPIRIT Alumni in completing individual tasks provided by superiors, analytical skills, time effectiveness in completion of tasks.

SPIRIT Alumni have an excellent ability to improve individual performance as well as to influence co-workers in terms of performance achieved in employee work objectives.

The flow of the re-entry program for SPIRIT Alumni after completing study placed first in the Secretariat. The placement period is about 6-1 years. Before putting in, the work unit given an individual assignment such as arranging the display of superiors/ministers, the post of organizational structure, while waiting for the needs in each group following the formations and disciplines owned. SPIRIT Alumni do not have to return to the original work unit. The period process of the SPIRIT alumni who are relatively long has caused Democultivation to SPIRIT Alumni.

Transfer of knowledge by SPIRIT Alumni in the Unit of work cannot yet be measured objectively; generally, it is done informally. The task that has a relatively high level of difficulty, SPIRIT Alumni can apply their knowledge and skills with teammates/colleagues in their work units.

\section{CONCLUSION}

For alumni of the degree program, the benefits gained from Spirit at this time are Alumni more trusted by superiors to perform daily tasks as well as ad-hoc tasks. The belief is obtained because in general, the capacity of alumni work increased compared to the earlier, especially in terms of the mindset is more systematic and able to think comprehensively, foreign language skills especially the English language, ready to prepare seminar/proposal paper even the speech script better, and can accomplish individual tasks that are urgent.

The benefits of the institution, especially for employers, are reliable Alumni to do essential tasks on a national scale. For example, Alumni are involved in a working team reviewing the improvement of the organizational structure of an institution using job analysis based on workload. Another example, an alumnus was given an assignment by the supervisor to engage in a team that set up a monitoring system for Climate Change activities in Indonesia based on information technology.

Another benefit is that Alumni can make a positive impact on the performance of colleagues through a supporting assignment. Indirectly, the coworkers will follow the Alumni mindset and working pattern. In specific things, there will be a transfer of knowledge, for example, in the application of IT, data processing methods, presentation models in the form of PowerPoint Interesting and practical.

Meanwhile, specifically for non-degree programs, Alumni and employers directly assess that non-degree programs are beneficial to Alumni and institutions because the topics and proposed training programmes tend to be Output Oriented. Means that the training programmes are more organized and submitted to Spirit based on the ad-hoc team's work needs. When an adhoc squad formed to assess a problem or formulate policy and the group requires individual skills that not yet owned, the team can apply for training using SPIRIT funds. Therefore, the results of the training will immediately felt at the moment. 
Analysis of Scholarship Program for Strengthening the Reforming Institution BPKP

Sofyan, Soleh, Tjiptadi, Sutisna

\section{REFERENCE}

Ainal, F. (2015). Pemaknaan Masyarakat Non-Muslim Di Banda Aceh Terhadap Pemberitaan Qanun Jinayat (Hukum Pidana Islam) di Harian Serambi Indonesia. Postgraduate Program in Communication Studies.

Arikunto, S. (2006). Prosedur penelitian suatu pendekatan praktik. Jakarta: Rineka Cipta.

Asra, A., Irawan, P. B., \& Purwoto, A. (2015). Metode penelitian survei. Jakarta: In Media.

Asra, A., \& Prasetyo, A. (2015). Pengambilan sampel dalam penelitian survei. Edisi Perdana, PT. Raja Grafindo Persada, Jakarta.

Beaulieu, M., Breton, M., \& Brousselle, A. (2018, February 1). Conceptualizing 20 years of engaged scholarship: A scoping review. PLOS ONE. Public Library of Science. https://doi.org/10.1371/journal.pone.0193201.

Boyer, E. L. (2016). The scholarship of engagement. Journal of Higher Education Outreach and Engagement. University of Georgia. https://doi.org/10.2307/3824459.

Fitri, A. (2015). Dramaturgi: Pencitraan Prabowo Subianto di Media Sosial Twitter Menjelang Pemilihan Presiden 2014. Interaksi: Jurnal Ilmu Komunikasi, 4(1), 101-108.

Norris-Tirrell, D., Lambert-Pennington, K., \& Hyland, S. (2010). Embedding service learning in engaged scholarship at research institutions to revitalize metropolitan neighbourhoods. Journal of Community Practice, 18(2), 171-189. https://doi.org/10.1080/10705422.2010.485850.

Ostrander, S. A. (2004). Democracy, Civic Participation, and the University: A Comparative Study of Civic Engagement on Five Campuses. Nonprofit and Voluntary Sector Quarterly. SAGE Publications Inc. https://doi.org/10.1177/0899764003260588.

Palombi, L. C., LaRue, A., \& Fierke, K. K. (2019). Facilitating community partnerships to reduce opioid overdose: An engaged department initiative. Research in Social and Administrative Pharmacy, 15(12), 1406-1414. https://doi.org/10.1016/j.sapharm.2018.07.002.

Roakes, S. L., \& Norris-Tirrell, D. (2000). Community service learning in planning education: A framework for course development. Journal of Planning Education and Research, 20(1), 100-110. https://doi.org/10.1177/073945600128992636. 